\title{
REMODELAÇÃO ESTÉTICA DO SORRISO E FECHAMENTO PARCIAL DE MORDIDA ABERTA COM RESINA COMPOSTA DOS INCISIVOS SUPERIORES
}

Keylla WITTMANN, Fábio SENE

Em alguns casos o uso da Dentística Restauradora tem sido uma alternativa para amenização da mordida aberta quando da não possibilidade cirúrgica. Paciente, sexo feminino compareceu na Clínica Odontológica da Universidade Estadual de Londrina apresentando como queixa principal mordida aberta ântero-superior. Verificou-se que a resolução mais indicada para o caso seria a cirurgia ortognática, mas a paciente se negava em fazê-la. Assim, foi realizado modelo de estudo e enceramento dos incisivos superiores onde verificou-se que seria possível fechar parcialmente a mordida aberta com aumento dos mesmos com resina composta. Primeiramente, com a resina Clear Trans (FILTEK SUPREME 3M-ESPE) foi realizado o aumento incisopalatino dos dentes. Em seguida, utilizaram-se as resinas OA3 e DA2 para confecção do corpo dentinário. Caracterizações foram feitas na região incisal e o esmalte vestibular confeccionado com a resina EA1. Como o dente 12 apresentava escurecimento severo foi realizado preparo para faceta direta seguido da colocação de uma primeira camada da resina composta WD para cobrimento da dentina escurecida. Após duas semanas, o acabamento e polimento final foram realizados. Conclui-se pelo resultado final obtido e pela reação da paciente que o planejamento e execução do caso com resina composta foram uma excelente alternativa para melhoria do sorriso da mesma.

Palavras-chave: Mordida aberta; Resinas compostas; Estética. 